\title{
PHYTOCHEMICAL ANALYSIS AND EVALUATION OF IN VITRO IMMUNOMODULATORY ACTIVITY OF RHODODENDRON ARBOREUM LEAVES
}

\author{
PRAMOD RAWAT, RAKESH KUMAR BACHHETI, NAVIN KUMAR, NISHANT RAI*
}

Department of Biotechnology, Graphic Era (Deemed to be University), Dehradun, Uttarakhand, India. Email: nishantrai1@gmail.com

Received: 20 February 2018, Revised and Accepted: 23 April 2018

ABSTRACT

Objectives: The objectives of this study are to analyze phytoconstituents in Rhododendron arboreum leaves (qualitatively and quantitatively) and to estimate the immunomodulatory effects of extracts using different in vitro methods for intracellular and phagocytic killing potency of neutrophils, which are subsequent, involved in the process of phagocytosis by neutrophils.

Methods: R. arboreum leaves extracts were separately extracted in 100\% methanol, $50 \%$ methanol, and aqueous by a hot percolation technique using Soxhlet apparatus and concentrated with a vacuum rotary evaporator apparatus. The percentage yield of the extracts wares calculated. The extract was used to analyze phytoconstituents qualitatively, and total phenolic and flavonoid content were estimated. In another study, already purified methanolic extract of $R$. arboreum leaves, namely cytoplasmic male sterility (CMS-3) (kaempferol), RAM fr2, and transcranial magnetic stimulation (TMS-10) (ursolic acid) was used to evaluate immunomodulatory activities by nitroblue tetrazolium test, phagocytosis of killed Candida albicans.

Results: Phytochemical screening of the extracts showed the presence of major classes of phytochemicals, i.e., phytosterols, flavonoids, phenols, alkaloids, carbohydrate, glycoside, sterols and steroids, terpenoids, and tannin while saponin was absent in all extract. The percent yield of leaves extract was $12.97 \%$. Total phenolic content (TPC) expressed as gallic acid equivalents (GAE) ranged $1327.5 \pm 0.009$ (in $100 \%$ methanolic extract), $1309.5 \pm 0.011$ (in 50\% methanolic), and $1468.5 \pm 0.006 \mathrm{mg} \mathrm{GAE} \mathrm{g}^{-1}$ dry weight (in aqueous extract). Total flavonoid content expressed as rutin

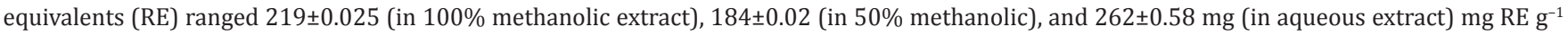
dry weight. R. arboreum purified extract CMS-3 (kaempferol), RAM fr2, and TMS-10 (ursolic acid) stimulated the neutrophils to phagocytic activity to the extent of $67.67 \pm 2.08 \%, 40.3 \pm 1.5 \%$, and $79.67 \pm 0.57 \%$, respectively. The above-said extracts stimulated the phagocytosis of killed $C$. albicans. The mean particle numbers for CMS- 3, RAM fr2, and TMS-10 were found to be 6.7, 6.3, and 7, respectively, at concentration $1 \mathrm{mg} / \mathrm{ml}$.

Conclusion: The phytochemical screening of all the extracts showed the presence of various phytochemicals that are biologically important. The total phenolic and flavonoid content of the plant are comparable to other medicinal plants. Even though the enormous progress on the phytochemistry and pharmacology of $R$. arboreum have been made, there still require more conclusive studies on the safety, efficacy, and in vivo toxicity of extracts and pure compounds to gain a better understanding.

Keywords: Rhododendron arboreum, Phytochemical, Ursolic acid, Kaempferol, Immunomodulatory activity.

(c) 2018 The Authors. Published by Innovare Academic Sciences Pvt Ltd. This is an open access article under the CC BY license (http://creativecommons. org/licenses/by/4. 0/) DOI: http://dx.doi.org/10.22159/ajpcr.2018.v11i8.25372

\section{INTRODUCTION}

Well-functioning and a strong immune system is the foundation of an excellent physical condition. The immunity is the balanced state of getting sufficient natural resistance to fight infection, the other redundant biological invasions although has tolerance to avoid autoimmune diseases and allergic reaction. Immune responses are a result of effective interaction between innate and acquired mechanism of an immune system. For the last three decades, researchers have shown a remarkable interest in the immune system as a potential target of toxicity due to exposure to environmental pollutants, chemicals and drugs. Immunodeficiencies arise as one or more components of the immune system are inactive. Several factors play an important role in altering the immune competence such as stress, lifestyle, sex, age, environmental contamination, malnutrition, alcohol/drug abuse, and genetic variability [1]. Immunomodulation is a wide term which refers to any changes or may involve amplification, expression, induction or inhibition of any part of the immune response. The immunomodulation concept has been gaining importance globally while researchers are realizing the immune system play a critical role in maintaining a disease-free condition. The incidence of life-threatening infections has increased significantly among AIDS patients, cancer patients, and transplant recipients, those receiving wide range cytotoxic drugs, corticosteroids, and antibiotics [1]. It seems that antibiotics have disappeared with their magic touch due to decades of improper use; reckless medication and unavoidable extent of bacterial genes give medicine resistance [2].

Phytochemicals give flavor, color, fragrance, and create a natural defense system for host plants. Till date, more than 4000 of these compounds have been discovered. The phytochemicals give protection to plants and also possess curative potential such as immunomodulatory activity, anti-diabetic, anticancer, anti-oxidant, adaptogenic property, enhancing memory, and cholesterol reducing effects. Discovery of thousands of phytochemicals was grouped based on source and function. Potential of natural compounds with immunostimulating activity will be classified as low molecular immunomodulatory compounds such as alkaloids, phenolic, and terpenoids whereas high molecular weight compounds are polysaccharides [3].

Mostofthechemotherapeuticagentsusually haveanimmunosuppressive activity which exerts a variety of side effects and cytotoxic. Due to which researchers motivated for investigating natural resources showing immunomodulatory activity. Several medicinal plants are recognized to have immunomodulatory properties and maintain natural resistance against disease through re-establishing the body's immune system such as Azadirachta indica [4], Terminalia chebula [5], and Lawsonia alba [6]. The phytochemical constituents such as tannins, proteins, steroids, and terpenoids [7], Flavonoids from Plantago species [8] and Syzygium samarangense [9] have also shown immunomodulatory activity. In vitro 
study of Vacha leaves alcohol, petroleum ether, and volatile oil extracts stimulate the phagocytosis in human neutrophils [10].

Various in vivo and in vitro test systems are used for assessing immunomodulatory activity. Phagocytosis is one such commonly used technique for screening the immune response [11]. Phagocytosis is the primary defense mechanism against any foreign bodies entering the body which is offered by macrophages and neutrophils. The process of phagocytosis consists of chronological stages such as motility, adhesion to microorganisms, ingestion of microorganisms, degranulation, and intracellular killing of microorganisms [12].

Rhododendron arboreum is one of the stateliest and impressive Rhododendron species where arboreum means tree-like [13]. Rhododendron is the state flower of Nepal and the state tree of Uttarakhand. It is enormously variable in stature, leaf characteristics, hardness, and flower color. It grows at elevations of $4500-10,500 \mathrm{ft}$. The tree attains a height of 40-50 ft tall occasionally attaining above $100 \mathrm{ft}$ [14]. This is an evergreen much-branched tree up to $2.4 \mathrm{~m}$ in girth and $14 \mathrm{~m}$ in height [15]. Flowering period is from March to April/June to September bearing crimson to pale pink or deep red flowers. $R$. arboreum methanolic extract of different parts (roots, stem, leaves, bark, and flowers) shows good antimicrobial and antifungal activity [16-18]. Chauhan et al. [19] discovered that the antibacterial activity of $R$. arboreum leaf extract was found effective as compared to flower extract against Staphylococcus aureus. Methanolic extract of $R$. arboreum leaves through gas chromatographymass spectrometry (GC-MS) analysis confirms the presence of main phytoconstituents, i.e., 22-stigmasten-3-one (14.59\%) with highest area percentage, followed by 1,1 , 6-trimethyl-3-methylene-2- $(3,6,10$, 13,14-pentamethyl-3-ethenyl-pentadec-4-enye) cyclohexane (12.26\%), beta-amyrin (7.62\%), and linoleyl alcohol (6.50\%) having antimicrobial, anticancer, antiarthritic, anti-inflammatory, and antiviral properties [20]. This plant is reported to possess several medicinal and pharmacological properties such as hepatoprotective, antioxidant, immunomodulatory, anti-inflammatory, anti-diabetic, anticancer, antinociceptive, adaptogenic, and antidiarrheal, oxytocic, estrogenic, prostragl, synthetase inhibitory activity, and central nervous system depressant activity [17,21-31]. In the present study, ursolic acid and kaempferol were quantitatively estimated from the $R$. arboreum leaves collected from Himachal Pradesh and its immunomodulatory properties were determined.

\section{METHODS}

Materials

All the chemicals used in the present study including standards were procured from Sigma-Aldrich, India; HiMedia.

\section{Collection of the samples}

$R$. arboreum leaves were collected from Ani-Jalori bypass district from Himachal Pradesh $\left(31^{\circ} 28^{\prime} 28.9524^{\prime \prime} \mathrm{N}, 7^{\circ} 25^{\prime} 21.3852^{\prime \prime} \mathrm{E}\right)$. The collected leaves were identified by Dr. S. K. Srivastava, Scientist "D" Botanical survey of India, Dehradun (Accession No: 115589). The collected leaves were washed thoroughly beneath fresh running water and were left for drying under a shed for 2 weeks. The dried leaves were then crushed in a blender and kept in sealed small bag in a refrigerator at $4^{\circ} \mathrm{C}$ until further use.

\section{Preparation of extract}

Initially, $R$. arboreum air-dried leaves (10 g) were crushed. The crushed $R$. arboreum leaves extracts were separately extracted in 100\% methanol, 50\% methanol (methanol: water: 1:1) and aqueous by hot percolation method using Soxhlet apparatus continuously for $8 \mathrm{~h}$. All the extracts were filtered, collected and concentrated using vacuum rotary evaporator dried and stored in the refrigerator at $4^{\circ} \mathrm{C}$ separately [32]. This extract was used to analyze phytoconstituents (qualitatively and quantitatively). R. arboreum air-dried leaves (130 g) were separately crushed and were extracted in different solvents with increasing polarity, namely petroleum ether < diethyl ether $<$ methanol by hot percolation method using Soxhlet apparatus continuously for $16 \mathrm{~h}$. The extract was filtered and concentrated using vacuum rotary evaporator, dried and stored in the refrigerator at $4^{\circ} \mathrm{C}$. The percentage yield of the extract was calculated after drying. Percentage yield of the plant extract was calculated using a formula:

$\%$ Yield of the extract $=\frac{C_{x}}{C_{y}} \times 100$

Where $C_{x}=$ plant material weight after extraction process; $C_{Y}=$ plant material weight taken for extraction.

In our previous studies, three constituents, namely cytoplasmic male sterility (CMS-3) (kaempferol), RAM fr2, and transcranial magnetic stimulation (TMS-10) (ursolic acid) were isolated/purified from them an ethanolic extract of $R$. arboreum leaves through thinlayer chromatography, column chromatography, and confirmed by HPLC. These purified extracts were used to evaluate in vitro immunomodulatory activities.

\section{Qualitative phytochemical screening}

The standard procedures were pursued to trace out the presence of phytochemicals in $R$. arboreum leaves, i.e., glycosides, flavonoids, anthocyanin, phenols, alkaloids, tannins, and saponins [33-35].

\section{Phytosterol identification}

\section{Salkowski reaction}

Half $(0.5) \mathrm{mg}$ of the extract was treated with $3 \mathrm{ml}$ concentrated sulfuric acid followed by $2 \mathrm{ml}$ of chloroform. Allow the mixture to stand for a minute. Formation of reddish-brown color in chloroform layer confirmed the presence of phytosterol [36,37].

\section{Liebermann Burchard's test}

Four mg of extract was treated with $0.5 \mathrm{ml}$ of chloroform and $0.5 \mathrm{ml}$ of acetic anhydride and then filtered. To the filtrate, few drops of concentrated sulfuric acid were added carefully along the side's wall of the test tubes. Formation of greenish-blue color indicates the existence of steroids [38].

\section{Test for phenols}

Two $\mathrm{ml}$ of distilled water was added to $1 \mathrm{ml}$ of extracts $(1 \mathrm{mg} / \mathrm{ml}$ ) followed by addition of some drops of $10 \% \mathrm{FeCl}_{3}$ (ferric chloride) and waited for the development of blue or green color.

\section{Alkaloids}

The extract was treated with $2 \%$ diluted HCL in boiling water bath for $2 \mathrm{~min}$. Allow to cool the mixture was filtered and treated with some drops of $5 \% \mathrm{NaOH}$ solution. The samples were observed for the presence of yellow precipitate or turbidity [39].

\section{Glycosides}

The extracts were neutralized by $\mathrm{NaOH}$ and hydrolyzed by $\mathrm{HCl}$ solution. Little drops of Fehling solution A and B were added and observed for red precipitate [33].

\section{Terpenoids}

Half $\mathrm{ml}$ of acetic anhydride was added to $4 \mathrm{~g}$ of extract. Then add $0.5 \mathrm{ml}$ of chloroform and concentrated $\mathrm{H}_{2} \mathrm{SO}_{4}$ to the mixture and observed for red violet color [39].

\section{Flavonoids}

Lead acetate test

The extract was treated with some drops of lead acetate solution. Development of yellow color precipitate indicates the presence of flavonoids [40].

Alkaline reagent test

Some drops of $\mathrm{NaOH}$ solution were added to the extract. Development of deep yellow color which disappears after adding diluted HCL shows the presence of flavonoids [41]. 
Tannins test

Mixed little amount of extract with water and heated on the water bath and filtered. Add few drops of ferric chloride to the filtrate. A dark green solution shows the existence of tannins [33].

\section{Saponins test}

Half $\mathrm{ml}$ of extract was dissolved in $5 \mathrm{ml}$ of distilled water and shaken for $15 \mathrm{~min}$. Persistence of frothing indicates that leaves extract contains Saponins [39].

Anthocyanin and Betacyanin test

One $\mathrm{ml}$ of leaves extract was dissolved in $1 \mathrm{ml}$ of $2 \mathrm{~N} \mathrm{NaOH}$ and was heated at $100^{\circ} \mathrm{C}$ in a water bath for $5 \mathrm{~min}$. The appearance of bluishgreen color shows the presence of anthocyanin while the development of yellow color indicated the presence of Betacyanin [42].

\section{Carbohydrate test}

Molisch test: Add $2 \mathrm{ml}$ of leaves extract to $1 \mathrm{ml}$ of Molisch reagent, and little drops of concentrated $\mathrm{H}_{2} \mathrm{SO}_{4}$ were added. Development of purple or reddish color shows the presence of carbohydrates [37-42].

Fehling's test

Add $2 \mathrm{ml}$ of leaves extract, $5 \mathrm{ml}$ of Fehling's solution A and B was kept in hot water bath for $5 \mathrm{~min}$. The development of yellow or red color shows the presence of carbohydrates [43].

\section{Quantitative phytochemical screening \\ Determination of total phenolic content (TPC)}

Folin-Ciocalteu reagent (FCR) assay was performed for the evaluation of TPC in the isolated plant extract [37,44-46]. Take $150 \mu$ l of the extract and mixed in $240 \mu \mathrm{l}$ of water and $150 \mu \mathrm{l}$ of $0.25 \mathrm{~N}$ FCR. It was incubated in the dark at room temperature for $3 \mathrm{~min}$. After incubation, add $300 \mu \mathrm{l}$ of $1 \mathrm{~N}$ $\mathrm{Na}_{2} \mathrm{CO}_{3}$, then the mixture was incubated further for $2 \mathrm{~h}$ inside dark at room temperature. Different dilutions of gallic acid $(0.01 \mathrm{mg} / \mathrm{ml}, 0.02 \mathrm{mg} / \mathrm{ml}$, $0.04 \mathrm{mg} / \mathrm{ml}, 0.08 \mathrm{mg} / \mathrm{ml}$, and $0.1 \mathrm{mg} / \mathrm{ml}$ ) were used as a standard for drawing the calibration curve. The absorbance of each sample was measured at $765 \mathrm{~nm}$, and results were expressed in terms of mg of gallic acid equivalent $\mathrm{g}^{-1}$ of extract* and were calculated using a formula:

$\mathrm{GAE}^{*}=\mathrm{X} \times \mathrm{V} \div \mathrm{M}$

Where X: Concentration of extract/standard (mg/ml), M: Weight of extract (g), V: Volume of extract (ml).

\section{Determination of total flavonoid content}

Total flavonoid content (TFC) assay was performed as suggested by Dae et al. [47], Dae through minor modifications. To $10 \mathrm{ml}$ extract, add $2 \mathrm{ml}$ of water and $150 \mu \mathrm{l}$ of $5 \% \mathrm{NaNO}_{2}$ solution. Allow the mixture to react for 6 min and then add $150 \mu \mathrm{l}$ of $10 \%, \mathrm{AlCl}_{3}$ solution and absorbance were measured after $15 \mathrm{~min}$ at the wavelength of $510 \mathrm{~nm}$. Rutin at different concentrations $(0.01 \mathrm{mg} / \mathrm{ml}, 0.02 \mathrm{mg} / \mathrm{ml}, 0.04 \mathrm{mg} / \mathrm{ml}, 0.08 \mathrm{mg} / \mathrm{ml}$, and $0.1 \mathrm{mg} / \mathrm{ml}$ ) were used as a standard for the quantification of total flavonoid. Triplicate measurements were carried out, and total flavonoid content was expressed in milligram of rutin equivalents (RE) $\mathrm{mg} / \mathrm{g}$ of extract ( $\left.\mathrm{mg} \mathrm{RE} \mathrm{g}^{-1}\right)^{*}$ and was calculated using formula.

$\mathrm{RE}^{*}=\mathrm{X} \times \mathrm{V} \div \mathrm{M}$

Where X: Concentration of extract/standard $(\mathrm{mg} / \mathrm{ml}), \mathrm{M}$ : Weight of extract (g), V: Volume of extract $(\mathrm{ml})$.

\section{Study of immunomodulatory activity}

Nitroblue tetrazolium test (NBT) [48,49].

Prepare the suspension of leukocytes $\left(5 \times 10^{6} / \mathrm{ml}\right)$ with $0.5 \mathrm{ml}$ of phosphate buffer saline (PBS) solution in 5 test tubes. A volume of $0.1 \mathrm{ml}$ PBS control and $0.1 \mathrm{ml}$ of end otoxin-activated plasma (LPS standard) was added to the $1^{\text {st }}$ and $2^{\text {nd }}$ tube, respectively. $100 \mu \mathrm{l}$ of test samples CMS-3, RAM fr2, and TMS-10 in $1000 \mu \mathrm{g} / \mathrm{ml}$ concentration were added in test tube no. 3, 4, and 5, respectively. Prepare fresh $0.15 \%$ NBT solution, add $0.2 \mathrm{ml}$ in each test tube and incubate at $37^{\circ} \mathrm{C}$ for $20 \mathrm{~min}$ then centrifuged at $1410 \mathrm{rpm}$ for 3-4 min to throw away the supernatant. These cells were re-suspended in the little quantity of PBS solution. A thin film was prepared on a glass slide, by air drying and followed by heat fixation and then counterstained by dilute carbol-fuchsin dye for $15 \mathrm{~s}$. The slides were rinsed under tap water, dried and observe under (100X) oil immersion microscope. The percent of NBT-positive cells those hold blue granules/ lumps were calculated by counting 200 neutrophils.

\section{Phagocytosis of killed Candida albicans [48-51]}

\section{Preparation of C. albicans suspension}

The C. albicans (MTCC -3017) was cultured in Sabouraud broth at $35^{\circ} \mathrm{C}$ for $24 \mathrm{~h}$ and then centrifuged at $4000 \mathrm{rpm}$ to pellet the cells at the bottom then the supernatant was discarded. The pellet cells were rinsed with sterile Hank's Balanced Salt Solution (HBSS) and centrifuged once more at $4000 \mathrm{rpm}$ and repeated the step for 3 to 4 times. The final cell pellet was mixed with a mixture of sterile HBSS and human serum in 4:1 proportion. The concentration of cell suspension $1 \times 10^{8}$ was used for the experiment.

\section{Slide preparation}

Put $0.2 \mathrm{ml}$ human blood on a sterile glass slide using finger prick method and allow to clot in an incubated at $37^{\circ} \mathrm{C}$ for $25 \mathrm{~min}$. Then blood clot was gently detached, and the slide was washed carefully with sterile normal saline so the adhered polymorphonuclear neutrophils (PMNs) (invisible) should be not removed. The slide was flooded with test samples RAM fr2, TMS-10, and CMS-3 in $1000 \mu \mathrm{g} / \mathrm{ml}$ concentration and incubated at $37^{\circ} \mathrm{C}$ for $15 \mathrm{~min}$. Then $C$. albicans suspension was added again incubated at $37^{\circ} \mathrm{C}$ for $1 \mathrm{~h}$. The glass slide was washed, fixed with methanol and stained with Giemsa stain.

\section{Phagocytosis evaluation}

The mean number of Candida cells phagocytosed through PMNs on the slide was determined microscopically for 100 granulocytes through morphological criteria. This number was used as a phagocytic index (PI) and was compared through basal PI control. A number of 200 neutrophils were examined to count the number of ingested Candidaassociated with each cell. The mean particle number associated with each cell was calculated.

\section{RESULTS}

\section{Qualitative phytochemical analysis}

The qualitative phytochemical analysis of $R$. arboreum leaves extract indicated the presence of phytosterols, flavonoids, phenols, alkaloids, carbohydrate, glycoside, sterols and steroids, terpenoids, and tannin while saponin was absent in all extract. The percentage yield of RAM extract was $12.97 \%$. Nisar et al. [33] explored that methanolic leaves extract contain flavonoids, steroids, terpenoids, anthraquinones, and tannins. Roy et al. [30] also showed the presence of phenolics, flavonoids, tannin, steroids, diterpenes, and triterpenes in the methanolic extract. Revealed the presence of hydrocarbon alkane, steroids, ester, fatty acids, flavonoids, terpenes, and organic compounds in the methanolic extract by GC-MS analysis and 49 phytochemicals were identified in the methanolic leaves extract of $R$. arboretum [20].

\section{Quantitative phytochemical analyses}

Analyze the antioxidant activity, total phenol content and total flavonoid content and their results were expressed as means \pm standard deviation (Table 1).

\section{TPC}

Different dilutions of the standard (gallic acid) were used to plot a standard calibration curve, resulting in with the linear equation, $\mathrm{Y}=4.0917 \mathrm{X}+0.0498$, and regression coefficient, $\mathrm{R}^{2}=0.988$. The TPC of $R$. arboreum in $100 \%$ methanolic, $50 \%$ methanolic, and $50 \%$ aqueous extract was found to be $1327.5 \pm 0.009 \mathrm{mg} / \mathrm{g}, 1468.5 \pm 0.006 \mathrm{mg} / \mathrm{g}$, and

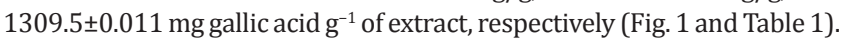


TFC

Different dilutions of rutin were used to plot a standard calibration curve, resulting in the linear equation, $\mathrm{Y}=1.3225 \mathrm{X}+0.0379$, and regression coefficient, $\mathrm{R}^{2}=0.996$. TFC value for the $100 \%$ methanolic and $50 \%$ methanolic extracts of $R$. arboreum was $219 \pm 0.025 \mathrm{mg}$ and $184 \pm 0.58 \mathrm{mg}$ rutin $\mathrm{g}^{-1}$ of extract, respectively, while aqueous extract showed the highest value of $262 \pm 0.023 \mathrm{mg}$ rutin $\mathrm{g}^{-1}$ of extract (Fig. 2 and Table 1).

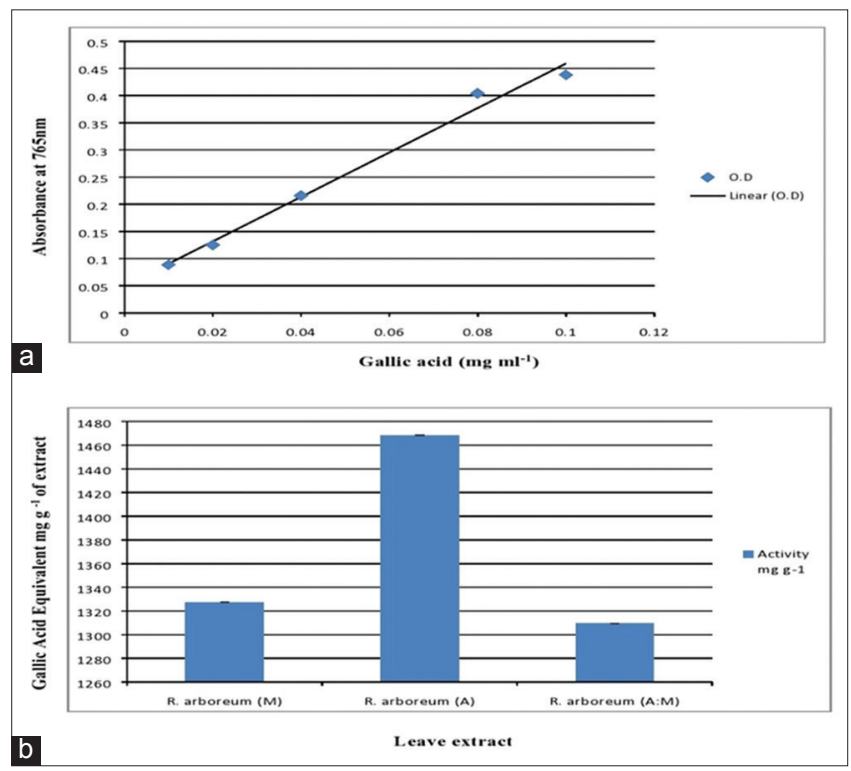

Fig. 1: Total phenolic content (TPC). (a) Calibration curve of gallic acid (b) TPC of different solvent extracts of Rhododendron arboreum

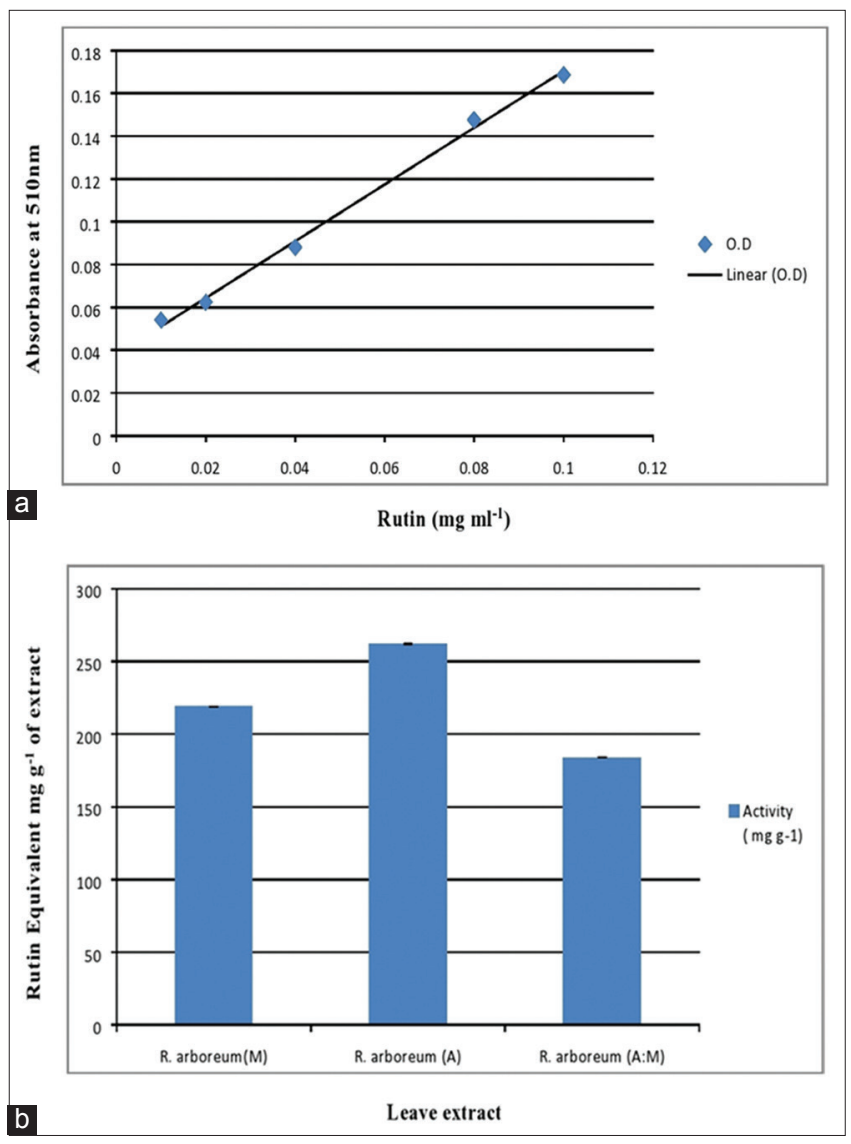

Fig. 2: Total flavonoid content (TFC). (a) Calibration curve of rutin (b) TFC of different solvent extracts of Rhododendron arboretum
NBT

R. arboreum purified extract CMS- 3 (kaempferol), RAM fr2, and TMS10 (ursolic acid) stimulated the neutrophils to phagocytic activity toward the extent of $67.67 \pm 2.08 \%, 40.3 \pm 1.5 \%$, and $79.67 \pm 0.57 \%$, respectively, when compared to normal control (PBS) $(21.3 \pm 0.57 \%)$ and positive control, i.e., endotoxin-activated plasma ( $82 \pm 1 \%)$ at same concentration. Leukocytes once stimulated, a membrane permeable, yellow-colored, water-soluble, and nitroblue tetrazolium are reduced to blue NBT formazan crystals by the leukocytes (Figs. 3 and 4).

\section{Phagocytosis of killed C. albicans}

R. arboreum purified extract CMS- 3 (kaempferol), RAM fr2, and TMS10 (ursolic acid) stimulated the phagocytosis of killed C. albicans. The mean particle numbers phagocytosis of killed C. albicans after treatment with CMS- 3, RAM fr2, and TMS-10 extract were found to be $6.7,6.3$, and 7 , respectively, at concentration $1 \mathrm{mg} \mathrm{ml}^{-1}$, when compared to positive control [6] (Figs. 5 and 6).

\section{CONCLUSION}

The phytochemical analysis concludes that $R$. arboreum leaves extract to contain various phytochemicals that are biologically important. The total phenolic and flavonoid content of the plant are comparable to other medicinal plants. The NBT assay and phagocytosis of killed C. albicans study are evidence that compounds in R. arboreum leave extract played

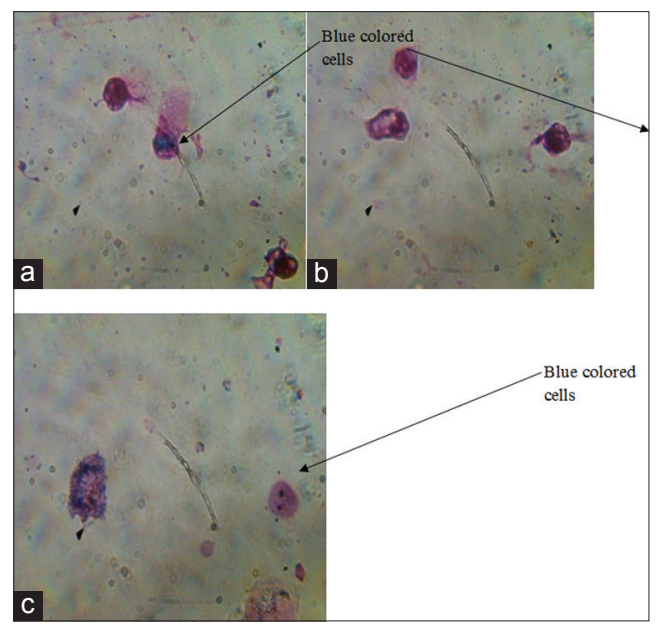

Fig. 3: Photograph showing neutrophils with reduced nitroblue tetrazolium test. (a) Neutrophil stimulation by cytoplasmic male sterility-3. (b) Neutrophil stimulation by RAM fr2. (c) Neutrophil stimulation by transcranial magnetic stimulation-10

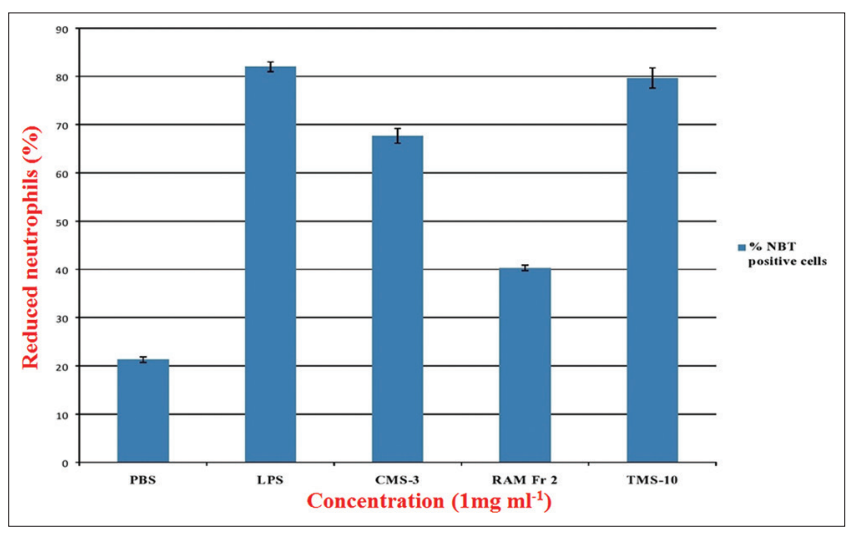

Fig. 4: Percent of reduced neutrophils treated with extracts by nitroblue tetrazolium test. Test extracts: Cytoplasmic male sterility-3, RAM fr2, and transcranial magnetic stimulation-10. Positive control: Endotoxin-activated plasma (LPS). Normal control: Phosphate buffer saline 
a significant role in the modulation of the immune response and thus may have application as an immunomodulatory agent. While huge progress on the pharmacology and phytochemistry of $R$. arboreum have been made, but still require more conclusive studies on the efficacy, safety, and in vivo toxicity of extracts and pure active compounds to gain a better understanding.

\section{ACKNOWLEDGMENT}

We acknowledge the Department of Biotechnology, Graphic Era University, Dehradun, for providing all laboratory facilities.

\section{AUTHOR'S CONTRIBUTION}

Conception and design of the work were done by Dr. Nishant Rai, Dr. Navin Kumar, and Mr. Pramod Rawat. Extraction/identification of phytochemical was done by Dr. Rakesh Kumar Bachheti and Mr. Pramod Rawat. Statistical analysis, interpretation of data and drafting of the

Table 1: Comparative phytochemical analyses of $R$. arboretum leaves extract in $\mathbf{1 0 0 \%}$ methanol and $50 \%$ aqueous

\begin{tabular}{lll}
\hline Extract & Phenolic $(\mathbf{m g} / \mathbf{g})$ & Flavonoid $(\mathbf{m g} / \mathbf{g})$ \\
\hline R. $\operatorname{arboretum}(\mathrm{M})$ & $1327.5 \pm 0.009$ & $219 \pm 0.025$ \\
R. $\operatorname{arboretum~(A)~}$ & $1468.5 \pm 0.006$ & $262 \pm 0.58$ \\
R. arboretum (A: M) & $1309.5 \pm 0.011$ & $184 \pm 0.023$ \\
\hline
\end{tabular}

Where $\mathrm{M}$ is methanol extract and $\mathrm{A}$ is aqueous. Each value is mean $\pm \mathrm{SD}$ value of

3 samples. SD: Standard deviation, R. arboretum: Rhododendron arboretum

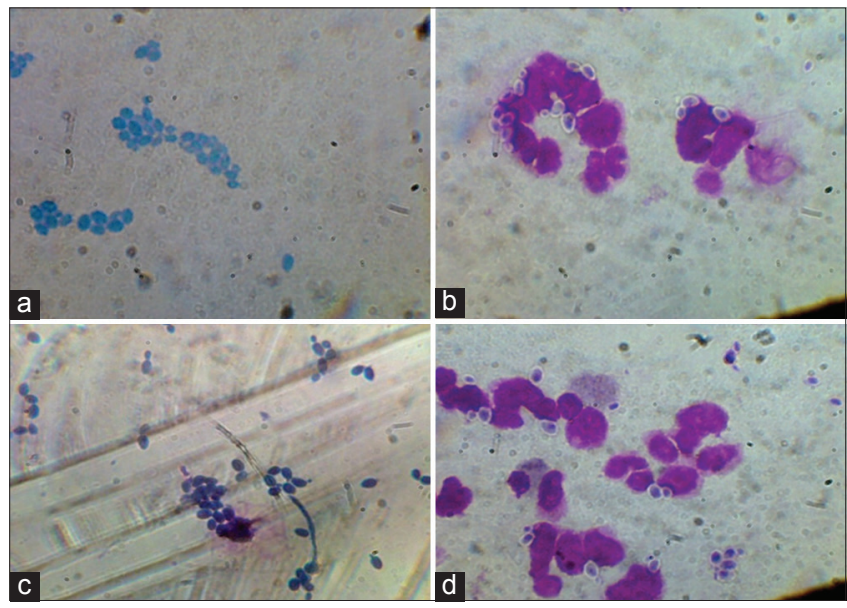

Fig. 5: Ingestion of Candida albicans by neutrophils. (a) C. albicans cells (100x). (b) Phagocytosis stimulation of $C$. albicans by cytoplasmic male sterility-3. (c) Phagocytosis stimulation of C. albicans by RAM fr2. (d) Phagocytosis stimulation of $C$. albicans by transcranial magnetic stimulation-10

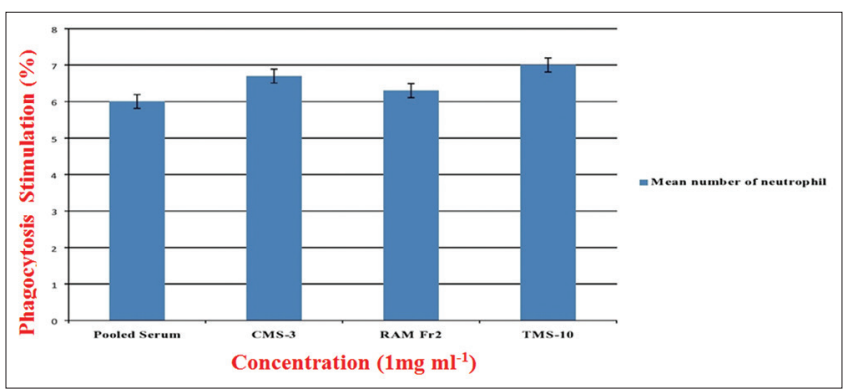

Fig. 6: Percent phagocytosis stimulation by Rhododendron arboreum extracts article were done by Mr. Pramod Rawat. Critical revision of the article was done by Dr. Nishant Rai, Dr. Navin Kumar Dr. Rakesh Kumar Bachheti and Mr. Pramod Rawat.

\section{CONFLICTS OF INTEREST}

The authors confirm no conflicts of interest.

\section{REFERENCES}

1. Anaissie EJ, Stratton SL, Dignani MC, Lee CK, Summerbell RC, Rex JH, et al. Pathogenic molds (including Aspergillus species) in hospital water distribution systems: A 3-year prospective study and clinical implications for patients with hematologic malignancies. Blood 2003;101:2542-6.

2. Njoroge GN, Bussmann RW. Diversity and utilization of antimalarial ethnophytotherapeutic remedies among the Kikuyus (Central Kenya). J Ethnobiol Ethnomed 2006;2:8

3. Wagner H. Structural analysis of a rhamnoarabinogalactan and arabinogalatans with immunostimulating activity from Calendula officinalis. Photochemistry 1999;28:2379-83.

4. van der Nat JM, Klerx JP, van Dijk H, de Silva KT, Labadie RP. Immunomodulatory activity of an aqueous extract of Azadirachta indica stem bark. J Ethnopharmacol 1987;19:125-31.

5. Sohni YR, Bhatt RM. Activity of a crude extract formulation in experimental hepatic amoebiasis and in immunomodulation studies. J Ethnopharmacol 1996;54:119-24.

6. Kulkarni SR, Karande VS. Study of the immunostimulant activity of napthoquinone extract of leaves of Lawsonia alba linn. Indian Drugs 1998;35:427-33

7. Biswas K, Chattopadhyay I, Banerjee RK, Bandyopadhyay U. Biological activities and medicinal properties of neem (Azadirachta indica). Curr Sci 2002;82:1136-345.

8. Chiang LC, Ng LT, Chiang W, Chang MY, Lin CC. Immunomodulatory activities of flavonoids, monoterpenoids, triterpenoids, iridoid glycosides and phenolic compounds of Plantago species. Planta Med 2003;69:600-4.

9. Kuo YC, Yang LM, Lin LC. Isolation and immunomodulatory effect of flavonoids from Syzygium samarangense. Planta Med 2004;70:1237-9.

10. Ravichandiran V, Vishal P. In vitro evaluation for immunomodulatory activity of Acorus calamus on human neutrophils. Int Res J Pharm 2015;6:450-2.

11. Ponkshe CA, Indap MM. In vivo and in vitro evaluation for immunomodulatory activity of three marine animal extracts with reference to phagocytosis. Indian J Exp Biol 2002;40:1399-402.

12. Daniel PS. In: Daniel PS, Abba IT, Tristram GP, editors. Basic and Clinical Immunology. $8^{\text {th }}$ ed. USA: Appleton and Lange; 1994. p. 195-215.

13. Orwa C, Mutua A, Kindt R, Jamnadass R, Simons A. Agroforestree Database: A Tree Reference and Selection Guide Version; 2009;4.0.

14. Rai T, Rai L Tress of the Sikkim Himalaya. New Delhi: Indus Publishing Company; 1994. p. 94.

15. Chauhan NS. Medicinal and Aromatic Plants of Himachal Pradesh. New Delhi: Indus Publishing Company; 1999. p. 353

16. Nisar M, Ali S, Qaisar M. Antibacterial and cytotoxic activities of the methanolic extracts of Rhododendron arboreum. J Med Plants Res 2013; 7:398-403.

17. Prakesh V, Rana S, Sagar A. Studies on antibacterial activity of leaf extracts of Rhododendron arboreum and Rhododendron campanulatum. Int J Curr Microbiol Appl Sci 2016;5:315-22.

18. Saranya D, Ravi R. The leaf of Nilgiri Rhododendron: A potent antimicrobial agent against medically critical human pathogens. Int $\mathrm{J}$ Pharmacog 2016;3:251-56.

19. Chauhan P, Singh J, Sharma RK, Easwari TS. Anti-bacterial activity of Rhododendron arboreum plant against Staphylococcus aureus. Indian J 2016;9:92-6.

20. Painuli S, Rai N, Kumar K. Gas chromatography and mass spectrometry analysis of methanolic extract of leaves of Rhododendron arboreum. Asian J Pharm Clin Res 2016;9:101-4.

21. Prakash D, Upadhyay G, Singh BN, Dhakarey R, Kumar S, Singh KK. Free radical scavenging activities of Himalayan Rhododendrons. Curr Sci 2007:92:526-32

22. Prakash T, Fadadu SD, Sharma UR, Surendra V, Goli D, Stamina P, et al. Hepatoprotective activity of leaves of Rhododendron arboreum in 
CCl4 induced hepatotoxicity in rats. J Med Plants Res 2008;2:315-20.

23. Sharma UR, Surendra V, Jha SK, Nitesh SC, Prakash T, Goli D. Evaluation of anti-inflammatory activity of Rhododendron arboreum herb extract on experimental animal. Arch Pharm Res 2009;1:58-61.

24. Verma N, Singh AP, Amresh G, Sahu PK, Rao CV. Antiinflammatory and antinociceptive activity of Rhododendron arboreum. J Pharm Res 2010;3:1376-80.

25. Verma N, Singh AP, Amresh G, Sahu PK, Rao CV. Protective effect of ethyl acetate fraction of Rhododendron arboreum flowers against carbon tetrachloride-induced hepatotoxicity in experimental models. Indian J Pharmacol 2011;43:291-5.

26. Srivastava P. Rhododendron arboreum: An overview. J Appl Pharm Sci 2012;2:158-62.

27. Sonar KP, Singh R, Bansal P, Balapure KA, SarafKS. R. arboreum flower and leaf extracts: RP-HPTLC screening, isolation, characterization and biological activity. Rasayan J Chem 2012;5:165-72.

28. Sonar PK, Singh R, Verma A, Saraf SK. Rhododendron arboreum (Ericaceae): Immunomodulatory and related toxicity studies. Orient Pharm Exp Med 2013;13:127-31.

29. Bhandari L, Rajbhandari M. Isolation of quercetin from flower petals, estimation of total phenolic, total flavonoid and antioxidant activity of the different parts of Rhododendron arboreum smith. Sci World 2014;12:34-40.

30. Roy JD, Handique AK, Barua CC, Talukdar A, Ahmed FA, Barua IC. Evaluation of phytoconstituents and assessment of adaptogenic activity in vivo in various extracts of Rhododendron arboreum (leaves). Indian J Pharm Biol Res 2014;2:49-56.

31. Nisar M, Ali S, Muhammad N, Gillani SN, Shah MR, Khan H, et al. Antinociceptive and anti-inflammatory potential of Rhododendron arboreum bark. Toxicol Ind Health 2016;32:1254-9.

32. Sindiri KM, Machavarapu M, Vangalapati M. Extraction, modeling and purification of flavonoids from Zephyranthes candida. J Int Acad Res Multidiscipl 2013;1:50-6.

33. Nisar M, Ali S, Qaisar M. Preliminary phytochemical screening of flowers, leaves, bark, stem and roots of Rhododendron arboreum. Middle East J Sci Res 2011;10:472-6.

34. Kiruba S, Mahesh M, Nisha SR, Miller P. Phytochemical analysis of flower extracts of Rhododendron arboretum sm. ssp. Nilagiricum tagg. Asian Pac J Trop Biomed 2011;S:284-6.

35. Saklani S, Chandra S. Evaluation of in vitro antimicrobial activity, nutritional profile and phytochemical screening of Rhododendron rboreum. World J Pharm Pharm Sci 2015:4:962-71.

36. Chandrashekar R, Rao SN. Phytochemical analysis of ethanolic extract of leaves of Lucasindica (Eelli). Int J Pharm Bio Sci 2013;4:33-8.
37. Chintalapani S, Swathi MS, Narasu ML. Phytochemical screening and in vitro antioxidant activity of whole plant extracts of Sesuvium portulacastrum L. Asian J Pharm Clin Res 2018;11:322-7.

38. Mathew S, Khosla KK, Mathew C, Bhowmik D. Preliminary phytochemical studies of Kalachoepinnata (Lam) Pers. J Med Plant Stud 2013;1:19-23.

39. Tariq AL, Reyaz AL. Phytochemical analysis of Camellia sinensis leaves. Int J Drug Dev Res 2012;4:311-6.

40. Peach K, Tracey MV. Modern Methods of Plant Analysis. Berlin Heidelberg: Springer Verlag; 1956. p. 125-7.

41. Ahuja J, Suresh J, Deep A, Pratyush M, Ravi. Phytochemical screening of aerial parts of Artemisia parviflora Rox b: A medicinal plant. Scholar Res Lib 2011;3:116-24.

42. Philip D, Kaleena PK, Valivittan K, Kumar CP. Phytochemical screening and antimicrobial activity of Sansevieria roxburghiana Schult and Schult. F Middle East Jof Sci Res 2011;10:512-8.

43. Mirela K, Vlasta P, Hribar J, Simcic M. Total phenol content and antioxidant activity of water solutions of plant extracts. Croat J Food Sci Technol 2009;1:1-7.

44. Singleton VL, Rossi JA. Colorimetry of total phenolics with phosphomolybdicphosph-tungstic acid reagents. Am J Enol Vitic 1965;16:144-58.

45. Kumar P, Pardhu G, Shruti R, Vijya L, Tejaswini K, Vishwanath PB. Phytochemical screening, antimicrobial and anti proliferative properties of Rhododendron ponticum on prostate epithelial cancer cells. J Pharm Sci Res 2011;3:1552-5.

46. Fidrianny I, Nadia E, Ruslan KW. In vitro antioxidant activities, total flavonoid, phenolic and carotenoid content from various extracts of four species Asteraceae herb. Int J Pharm Pharm Sci 2015;7:192-7.

47. Dae OK, Seung WJ, Chang YL. Antioxidant capacity of phenolic phytochemicals from various cultivars of plums. Food Chem 2003;81:321-6.

48. Patil JK, Jalalpure SS, Hamid S, Ahirrao RA. In-vitro immunomodulatory activity of extracts of Bauhinia vareigata Linn stem bark on human neutrophils. Iran J Pharm Ther 2010;9:41-6.

49. Yadav S, Bhargav M, Ramya R, Laureen, Habeeb N. In-vitro antioxidant and immunomodulatory activity of Citrullus lanatus seed. Int J Eng Sci Res Technol 2016;679-85. DOI: 10.5281/zenodo.212024.

50. Parameshwara C, Jalalpure SS, Jagwani S, Kumar N, Shah B. Phytochemical investigation and in-vitro immunomodulatorystudy of Asparagus racemosus wild roots extracts. Pharm Sci Monitor 2015;6:292-9.

51. Kupati VB, Jadar PG. Immunomodulatory effects of ayurvedic drugs: A review. Indian J Appl Res 2014;4:28-30. 